\title{
An Analysis of Depictive Secondary Predicates in German without Discontinuous Constituents
}

\author{
Stefan Müller \\ Universität Bremen \\ Proceedings of the 11th International Conference on \\ Head-Driven Phrase Structure Grammar \\ Center for Computational Linguistics, Katholieke Universiteit Leuven \\ Stefan Müller (Editor) \\ 2004 \\ CSLI Publications \\ pages 202-222 \\ http://csli-publications.stanford.edu/HPSG/2004
}

Müller, Stefan. (2004). An Analysis of Depictive Secondary Predicates in German without Discontinuous Constituents. In Stefan Müller (Ed.): Proceedings of the 11th International Conference on Head-Driven Phrase Structure Grammar, Center for Computational Linguistics, Katholieke Universiteit Leuven (pp. 202-222). Stanford, CA: CSLI Publications. 


\begin{abstract}
In Müller, To Appear 2005b I provide evidence that suggests that linearization approaches that analyze German clause structure with discontinuous constituents cannot account for the German clause structure in an insightful way. In order to eliminate the very powerful concept of linearization domains and discontinuous constituents from the grammar, analyses of other phenomena which also rely on discontinuous constituents should therefore be revised.

In this paper, I develop an analysis of German depictive secondary predicates that differs from the one suggested in Müller, 2002 by assuming binary branching structures, verb movment, and continuous constituents instead of a linearization approach. Some shortcomings of previous analyses are pointed out and it is shown how linearization constraints regarding depictive predicate and antecedent can be modeled.
\end{abstract}

\title{
1 Introduction
}

This paper deals with depictive secondary predicates, examples of which are given in (1):

(1) a. Erißt das Fleisch $\operatorname{roh}_{i}$. he eats the meat raw

b. $\mathrm{Er}_{i}$ ißt das Fleisch nackt ${ }_{i}$. he eats the meat naked

In German, uninflected adjectives and prepositional phrases may appear as depictive predicates, as the examples in (1) and (2) show.

(2) Ich habe ihn (gestern) im dunklen Anzug getroffen. ${ }^{1}$

I have him yesterday in.the dark suit met

'I met him in a dark suit yesterday.'

Depictives say something about a state that holds for a participant of an event during the event.

Depictives pattern with adjuncts in terms of Focus Projection (Winkler, 1997, p. 310) and linearization in the so-called Mittelfeld (Müller, 2002, Chapter 4.1.4).

To establish the predication relation between the depictive predicate and its antecedent, I suggested a coindexing analysis, in which the subject of the depictive is coindexed with an element of the argument structure of the modified verb. Since the depictive is not necessarily adjacent to the verb and since the argument structure is usually not projected, I suggested an analysis that makes use of discontinuous constituents.

\footnotetext{
${ }^{\dagger}$ I want to thank two anonymous reviewers of HPSG 2004 for comments on an earlier version of this paper. I also thank all participants of HPSG 2004 and in particular Berthold Crysmann and Tibor Kiss for discussion.

${ }^{1}$ See Helbig and Buscha, 1972, p. 556 for a similar example.
} 
Considering new data with multiple constituents in front of the finite verb, I developed an analysis of German clause structure which makes discontinuous constituents superfluous for accounting for verb placement and constituent serialization (Müller, To Appear 2005a,Müller, To Appear 2005b).

In the following paper I develop an analysis of depictive secondary predicates that does not require discontinuous constituents, but nevertheless uses binary branching structures and that fits into the general fragment of German that is outlined in Müller, To Appear 2005a.

The paper is structured as follows: In Section 2 I discuss the phenomenon of depictive secondary predicates in more detail. I show that reference to non-overt antecedents (Section 2.1) and oblique antecedents (Section 2.2) is possible. The reference to non-arguments (Section 2.3) and to elements inside of arguments (Section 2.4) is excluded. In Section 2.5 I discuss linearization of depictive secondary predicates with regard to their antecedents. In Section 3, I discuss previous analyses and their problems. Section 4 gives an brief introduction to basic assumptions regarding the analysis of clause structure in the framework of HPSG and Section 5 provides the analysis of depictive secondary predication.

\section{The Phenomenon}

\subsection{Non-Overt Antecedents}

(3) shows that reference to unexpressed subjects is possible: ${ }^{2}$

(3) a. daß das Buch nackt gelesen wurde ${ }^{3}$ that the book naked read was

'that the book was read naked'

b. daß das Buch nackt zu lesen ist that the book naked to read is

'The book is to be read naked.'

Example (3a) is a passive construction and in (3b) we have a modal infinitive.

Zifonun (1997, p. 1803) gives the following example and claims that the depictive predicate cannot refer to the logical subject of the passivized verb. ${ }^{4}$

(4) Die Äpfel wurden ungewaschen in den Keller getragen.

the apples were unwashed in the basement carried

'The apples were carried to the basement unwashed.'

\footnotetext{
${ }^{2}$ See also Paul, 1919, p. 51, Plank, 1985, p. 175, Jacobs, 1994, p. 297, Grewendorf (1989, p. 129; 1993, p. 1313) Haider, 1997, p. 6 and Müller, 1999, p. 320 for examples for predication over nonovert antecedents in German and Baker, 1988, p. 318 for English examples.

${ }^{3}$ See Müller, 2002, p. 177 for a similar example.

${ }^{4}$ Jaeggli (1986, p. 614)—following Chomsky (1986, p. 121)—makes a similar claim for English. As the translations of the examples in (3) show, this claim is as wrong for English as it is for German.

Chomsky claims that only a syntactically present element can be the subject of adjectival predication. This includes PRO but excludes predication over passive subjects.
} 
That the reading in which the depictive refers to the agent of the carrying is hardly available is probably due to a preference rule that makes readings where a depictive refers to an non-overt antecedent dispreferred. If the reading in which the depictive refers to the logical object of the main verb is semantically implausible, the reference to the logical subject of the main verb is fine as the examples in (3) show.

Reference to non-overt logical subjects is also possible with intransitive verbs:

(5) a. Auf dem Land fahren alle betrunken. on the country drive all drunk 'Everyone drives drunk in the country.'

b. Auf dem Land wird auch betrunken gefahren. on the country is also drunk driven

'There is also driving drunk in the country.'

According to Bresnan (1982, p. 416-417) similar examples in Icelandic and Norwegian are ungrammatical. Bresnan derives this from a theory that predicts that the passivization of intransitive verbs whose subject functionally controls a predicate complement is impossible. The HPSG equivalent of functional control is sharing of SYNSEM values, i.e., sharing of syntactic information like case and of semantic information. To account for (5) Bresnan had to assume that the relation between German state predicates and their antecedents is anaphoric control rather then functional control as in Icelandic and Norwegian. The HPSG equivalent of anaphoric control is sharing of referential indices. Alternatively, she could assume that state predicates are not complements in German. In Section 5, I will develop a coindexing-analysis that assumes depictives to be adjuncts.

Depictive predicates can also refer to the non-expressed subject of an adjectival participle:

(6) die [N, [AP nackt schlafende] Frau]

the naked sleeping woman

'the woman who is sleeping naked'

In (6) Frau is coreferent with the syntactic and the logical subject of schlafende. Frau is not syntactically realized in a projection of the deverbal adjective.

Grewendorf (1989, p. 129; 1993, p. 1313) and Haider (1997, p. 6) discuss the examples in (7a) and (7b), respectively.

(7) a. Der Doktor untersucht _ nur nüchtern. the doctor examines only sober

b. Dieser Arzt $_{i}$ untersucht $\left(\right.$ Patienten $_{j}$ ) nur unbekleidet ${ }_{i / j}$. this doctor examines patients only undressed

Grewendorf assumes the non-overt subject of nüchtern to be the empty pronominal element pro. Haider (1997, p. 28) assumes that depictive predicates are generated adjacent to the DP they predicate over. Therefore he is forced to assume some 
empty referential element in cases like $(7 b)^{5}$ and also in passive examples like (3). However, in GB-theory it is usually assumed that the passive participle does not assign a theta role to its logical subject (Chomsky, 1993, p. 124). Grewendorf (1993, p. 1311) assumes that the subject of impersonal passives as in (5) is an expletive pro. Haider (1993, p. 134) assumes that there is no subject in impersonal passive constructions. So, irrespective of the particular approach to passive, there is no element, overt or non-overt, that bears the theta role of the logical subject and that could function as an antecedent of a depictive.

\subsection{Reference to Oblique Antecedents}

The examples in (1) show that depictives may refer to subjects and to accusative objects. In this subsection I want to discuss the possibility of depictives to refer to more oblique elements.

Haider (1985, p. 94) observes that the predication over a dative object in (8b) is marked in comparison to predication over accusative objects. In (8a) both reference to the subject and to the accusative object is possible, while the reading with reference to the object is hardly available in $(8 b)$.

$$
\begin{aligned}
& \text { a. } \operatorname{Er}_{i} \quad \text { sah } \operatorname{sie}_{j} \quad \text { nackt }_{i / j} . \\
& \text { he }_{\text {nom }} \text { saw her }_{a c c} \text { naked } \\
& \text { b. } \operatorname{Er}_{i} \text { half } \operatorname{ihr}_{j} \quad \text { nackt }_{i / ? ? j} . \\
& \text { he }_{\text {nom }} \text { helped her } \text { hat }_{\text {dat }} \text { naked }
\end{aligned}
$$

Haider concludes that depictive predicates can refer to NPs with structural case only. According to Haider, only nominative and accusative are structurally assigned cases in verbal environments while dative is not. As Haider notes, this could be explained easily by the assumption that the subject of the predicate and the NP it refers to are identical. The fact that in German, NP subjects always have structural case explains why a depictive element cannot refer to a dative NP, because dative is taken to be a lexical case.

Wunderlich (1997, p. 131) develops an analysis for depictives that posits two different subanalyses: one for depictives that refer to the subject (VP-adjuncts), and another one for depictives that refer to the direct object (V-adjuncts). Datives (including dative objects of verbs like helfen) are assumed to be indirect objects. Therefore he predicts that reference to dative NPs is not possible. Kaufmann and Wunderlich (1998, p. 9) claim that the predication of depictive and resultative predicates over indirect objects is excluded in all languages.

While these statements refer to syntactic case, similar claims can be found with regard to semantic roles. Discussing (9), Rothstein (1985, p. 85) assumes a restriction that allows depictives in English to refer to agents and patients, but not to goals.

\footnotetext{
${ }^{5}$ In Haider, 1993, p. 180, he assumes that the omited argument in (7) is treated as an implicit argument and not as an empty, pronominal element. This is the view that I adopt in the following.
} 


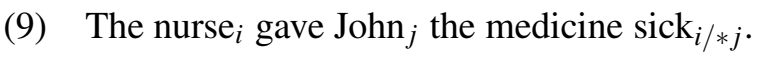

A similar claim is made by Koch and Rosengren (1995, p. 80), who claim that only reference to agent or theme is allowed. ${ }^{6}$ That the reference to thematic roles is not suited for the explanation of the possible antecedents was noted by Koizumi (1994, p. 46-48). His examples are given in (10a, b). Simpson (In Preparation) provides the additional example in $(10 \mathrm{c})$ :

(10) a. They gave the patients $s_{j}$ the drugs drunk ${ }_{* j}$.

b. The patients $j_{j}$ were given the drugs drunk $_{j}$.

c. After being given the drugs drunk ${ }_{j}$, the patients ${ }_{j}$ complained.

That the exclusion of reference to datives is not a hard constraint is shown by examples like (11):

(11) $\operatorname{Man}_{i}$ half $\operatorname{ihm}_{j}$ erst halbtot $_{i j j}{ }^{7}$

one $_{\text {nom }}$ helped him ${ }_{\text {dat }}$ only half.dead

'One helped him only half dead.'

In (11) the context favors the reading with reference to the dative object: Since it is implausible that half dead people help others, the subject is not a plausible antecedent candidate in (11). In general, it can be said that the reference to dative NPs improves considerably if the reference to the nominative is excluded by world knowledge (Plank, 1985, p. 175).

The reference to the dative in (8b) improves, if we passivize the sentence: In (12) the reference to the dative NP is considerably better than in ( $8 b)$, where another candidate for coreference appears at the surface.

(12) $\operatorname{Ihr}_{j} \quad$ wurde nackt $i / j$ geholfen.

her $_{d a t}$ was naked helped

'She was helped naked.'

Of course, the sentence in (12) has a reading where the helper is naked. This reading is indicated by the $i$-index at $n a c k t$, which does not appear anywhere else in the sentence.

Simpson (In Preparation) notes that changing the polarity and modality to force a generic conditional interpretation improves reference to recipient/goal arguments. Her English example can be translated to German:

(13) $\mathrm{Du}$ kannst ihnen bewußtlos keine Spritzen geben. you $_{\text {nom }}$ can them dat $_{\text {unconscious no injections }}$ acc give 'You can't give them injections unconscious.'

\footnotetext{
${ }^{6}$ On page 4 they make this claim with reference to grammatical functions, i. e. subject and direct object.

${ }^{7}$ Plank, 1985, p. 175.
} 
From the data presented above it must be concluded that both the restriction on the case of possible antecedent phrases and the restriction on the thematic role of the antecedent phrase are not adequate. In what follows, I will therefore assume that the subject of the depictive predicate is coindexed, i. e. coreferent with, the antecedent phrase. I do not assume that the subject of the depictive and the antecedent are identical, as was suggested by Haider.

\subsection{Reference to Non-Arguments}

NPs in adjuncts are excluded from the list of possible referents of depictives as (14) shows.

a. weil $\operatorname{Karl}_{i}\left[\right.$ neben Maria $\left.{ }_{j}\right]$ nackt $_{i * j}$ schlief.

because Karl next Maria naked slept

'because Karl slept next to Maria naked.'

b. weil [neben Maria ${ }_{j}$ nackt $_{i / * j}$ geschlafen wurde.

because next Maria naked slept was

Intended: 'because somebody slept next to Maria while she was naked.'

Even passivizing the sentence as in (14b) does not improve the reference to an element inside of the adjunct.

\subsection{Reference to Elements inside of Arguments}

The reference to NPs that are internal to other NPs is also excluded, as is demonstrated by $(15):^{8}$

(15) a. daß Jan [den Freund von $\left.\mathrm{Maria}_{i}\right]$ nackt $_{* i}$ traf. that Jan the friend of Maria naked met

'that Jan met the (male) friend of Maria naked.'

b. daß Jan $\left[\right.$ Marias $_{i}$ Vater] nackt Ni $_{* i}$ traf. that Jan Maria's father naked met 'that Jan met Maria's father naked.'

c. * daß Jan [Maria nackt und ihren Freund] traf. that Jan Maria naked and her friend met Intended: 'that Jan met Maria naked together with her friend.'

\subsection{Linearization of Depictives with Regard to Their Antecedents}

As Lötscher (1985, p. 208) pointed out, the antecedent of the depictive predicate has to precede the depictive:

\footnotetext{
${ }^{8}$ Neeleman (1994, p. 157) gives Dutch examples that are equivalent to those in (15a,b).
} 
(16) a. weil er $_{i}$ die $_{\text {Äpfel }}$ ungewaschen $_{i / j}$ ißt.

because he the apples unwashed eats

'because he eats the apples unwashed.'

(He is unwashed or the apples are unwashed.)

b. weil er $_{i}$ ungewaschen $_{i / * j} \operatorname{die~} \ddot{\text { Apfel }}_{j}$ ißt. $_{\text {int }}$

because he unwashed the apples eats

'because he eats the apples unwashed.'

(He is unwashed.)

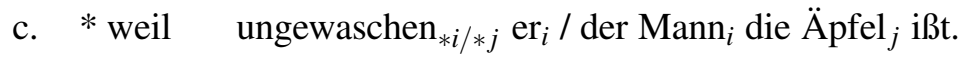

because unwashed he the man the apples eats

In example (16a) the adjective may refer to either er or to die Äpfel. In (16b) the reference to die Äpfel is excluded. Only the reading in which ungewaschen refers to $e r$ is available. The example (16c) in which the depictive precedes both of the possible antecedents is ungrammatical.

There are examples like (17) that do not follow this pattern, but these are instances of so-called I-topicalization (Jacobs, 1997), which can also be observed with parts of the predicate complex that usually have a fixed position, and which therefore should be analyzed similar to extraction.

(17) weil betrunken niemand $_{i}$ hereinkommt. $^{9}$

because drunk nobody $_{\text {nom }}$ in.comes

'because nobody gets in drunk.'

See also Haider (1997, p. 29-30), who suggests a special treatment of sentences in which the depictive precedes the subject.

I will not deal with sentences like (17) here.

\subsection{Summary of the Data Discussion}

The reference to subjects, direct objects, and indirect objects is possible. Therefore a raising analysis that identifies the subject of the depictive predicate with its antecedent is not adequate since the subject has structural case and dative objects bear lexical case. A coindexing analysis on the other hand is compatible with the data.

Reference to non-overt elements is possible and reference to adjuncts or elements embedded in arguments is not possible. So an analysis is needed that coindexes the subject of the depictive with one argument of the modified verb.

Finally, it was noted that the antecedent has to precede the depictive predicate.

\section{Previous Analyses and Analysis Options}

In this part of the paper I want to discuss analyses that were suggested or that seem to be options. In Section 3.1 it is shown that a direct coindexation of elements

\footnotetext{
${ }^{9}$ von Stechow and Sternefeld, 1988, p. 466.
} 
of the argument structure with the subject of the depictive predicate is not possible if binary branching structures without projection of the argument structure are assumed. I will then explore alternatives.

\subsection{Projection of the Argument Structure}

Kaufmann (1995, p. 87-88) noted that accounts with binary branching structures have problems with examples like (18), if the argument structure is not projected.

(18) weil er nackt der Frau hilft.

because he naked the woman helps

'because he helps the woman naked.'

The analysis of (18) is shown in Figure 1. In what follows I assume a version of

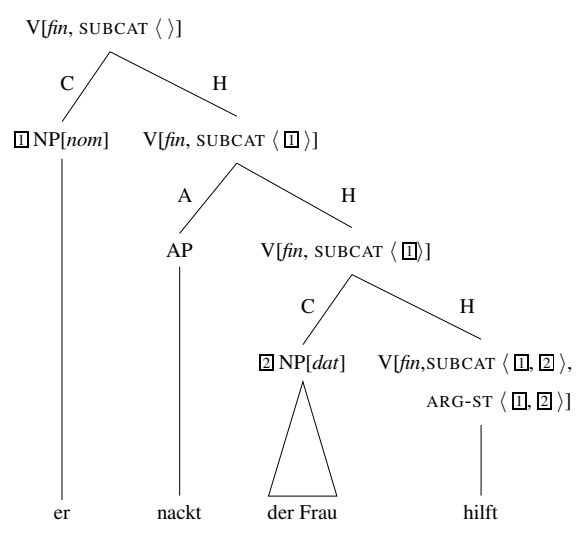

Figure 1: The Problem of Accessibility of the Argument Structure

Head-Driven Phrase Structure Grammar (Pollard and Sag, 1994) as the underlying framework. ARG-ST is a list that contains all arguments of a head. The SUBCAT list differs from ARG-ST in that arguments that are combined with their head are not represented at the SUBCAT list of the mother node.

The combination of der Frau and hilft in Figure 1 is phrasal and therefore does not have an ARG-ST that could be used to establish the coindexing, since ARG-ST usually is a feature which is appropriate for lexical items only.

The problem of an approach that projects the argument structure is that it becomes possible to select internal properties of phrases, since all information about the valence of a head becomes available at the maximal projection of the head. This basically enables non-local selection which should be impossible in principle (see Pollard and Sag, 1994, p. 23 on the locality of selection).

In the following I discuss alternatives where a projection of the argument structure is not necessary. 


\subsection{Flat Structures}

A possible solution to the problem of accessibility of the argument structure could be the assumption of a flat structure for the German clause as was suggested for instance by Uszkoreit (1987) in the framework of GPSG and by Pollard (1996) and Kasper (1994) in the framework of HPSG. In order to account for adjuncts in such an analysis, Kasper assumed complex relational constraints that traverse the daughters of the flat structure and compute the meaning of a clause. The relational constraint that is needed for this is quite complex and an analysis that can do without such machinery would be the preferred one. See also Müller, 2004 for discussion.

While the need for relational constraints is not an empirical argument against flat structures, the examples in (19) are: ${ }^{10}$ Usually only one constituent can appear in front of the finite verb in German. However there are examples like (19) that seem to be exceptions to this rule:

(19) a. [Alle Träume] [gleichzeitig] lassen sich nur selten verwirklichen. ${ }^{11}$ all dreams simultaneously let self only rarely realize

'All dreams can seldom be realized at once.'

b. [Dauerhaft] [mehr Arbeitsplätze] gebe es erst, wenn sich eine lasting more jobs give $_{c o n j}$ it only when self a Wachstumsrate von mindestens 2,5 Prozent über einen Zeitraum von growth.rate from at.least 2.5 percent over a period from drei oder vier Jahren halten lasse. ${ }^{12}$ three or four years hold let

'A long-term fall in unemployment can only be expected if a growth rate of at least 2.5 percent can be maintained over a period of three or four years.'

c. [Los] [damit] geht es schon am 15. April. ${ }^{13}$

PART there.with goes it already at 15 April

'It already starts at 15th of April.'

The position in front of the finite verb can be filled by various combinations of elements. Adjuncts, arguments, and predicate complex forming constituents can appear there. These constituents are linearized as if they were part of the German Mittelfeld, right sentence bracket or Nachfeld: The normal linearization of the examples in $(19 a, b)$ is shown in (20):

(20) a. daß sich nur selten alle Träume gleichzeitig verwirklichen lassen that self only seldom all dreams simultaneously realize let

\footnotetext{
${ }^{10}$ See Müller, 2003 for an extensive documentation of this phenomenon.

${ }^{11}$ Brochure from Berliner Sparkasse, 1/1999

${ }^{12}$ taz, 19.04.2000, p. 5

$13_{\text {taz, } 01.03 .2002, \text { p. } 8 .}$.
} 
b. weil es dauerhaft mehr Arbeitsplätze erst gebe, wenn because it lasting more jobs only give if

If the elements are reordered the result gets marked:

a. ?* weil sich nur selten gleichzeitig alle Träume because self only seldom simultaneously all dreams verwirklichen lassen.

realize let

b. ?* weil es mehr Arbeitsplätze dauerhaft erst gebe, wenn .... because it more jobs lasting only give if

As was pointed out by Susan Olsen (p. c. 2001), the same is true for the ordering of elements in front of the finite verb: If they are serialized in an order that does violate the constraints that can be observed for constituents in the Mittelfeld, the sentences get marked (see also Eisenberg, 1994, S. 412-413).

a. ?* Gleichzeitig alle Träume lassen sich nur selten verwirklichen. simultaneously all dreams let self only seldom realize

b. ?* Mehr Arbeitsplätze dauerhaft gebe es erst, wenn .... more jobs lasting give it only if

The particle in (19c) and (23) occupies the right sentence bracket. The pronominal adverb in (19c) is extraposed, the usual position would be some position in the Mittelfeld as shown in (23):

(23) daß es (damit) schon am 15. April (damit) losgeht

The data in (19) - (23) can only be accounted for if one assumes that the constituents in front of the finite verb are part of a verbal projection. For more evidence see Müller, 2003. In verb movement approaches to verb initial sentences a trace is assumed in the right sentence bracket. The very same empty element can be used to account for the verbal properties of the material in front of the finite verb in sentences like (19): The V2 property of German can be maintained and the linearization properties of the elements in multiple frontings are explained (Müller, To Appear 2005b).

Flat accounts cannot account for sentences like (19) without stipulation, since there is nothing that would license a verbal projection in front of the finite verb.

\subsection{Adjuncts as Complements}

Van Noord and Bouma (1994) and Bouma et al. (2001) suggested a lexical treatment of adjuncts: Adjuncts are introduced into valence lists by lexical rules or relational constraints. If this analysis is applied to depictives, depictives are introduced lexically and therefore a coindexation with one element of the argument structure is possible. Such a lexical analysis of depictives as lexically introduced $\mathrm{V}$-adjuncts is suggested by Wunderlich (1997). 
As Levine (2003) noted, adjuncts-as-complements analyses have problems in getting scope facts in coordinated structures right in which an adjunct scopes over several coordinated verbs. Instead of allowing for a reading where the adjunct scopes over a conjoined event, only scope over events belonging to the respective verbs is predicted since adjuncts are introduced as dependents of a single verb.

The scope problem found by Levine also extends to depictives, as the following example by Andrew McIntyre shows:

(24) The professor drove to the university, held a lecture and met with his doctoral students stoned (the whole time).

The depictive scopes over all three events, i.e., over drove, held, and met. Similarly in (25) a reading has to be possible, where the person who set the table and who did the dishes was naked the whole time.

(25) weil er nackt den Tisch gedeckt und abgewaschen hat because he naked the table set and the.dishes.done has 'because he set the table and did the dishes naked.'

\subsection{Binding Theory}

The data discussed so far could be analyzed parallel to what was suggested by Pollard and Sag (1994, Chapter 6.8.3) for control: The subject of a controlled VP like in (26a) is assumed to be a reflexive pronoun, which has to be bound in its binding domain, i.e., to an element that is less oblique than the controlled VP. ${ }^{14,15}$

(26) a. John promised Bill to leave.

b. promise: ARG-ST $\left\langle\mathrm{NP}_{i}(, \mathrm{NP}), \mathrm{VP}\left[\mathrm{SUBJ}\left\langle\mathrm{NP}:\right.\right.\right.$ ref $\left.\left.\left._{i}\right\rangle\right]\right\rangle$

In order to make such an analysis work, one has to assume that depictives are members of the list that is relevant for binding. Nowadays this is the ARG-ST list. However, if the depictive is part of the ARG-ST list and as such is mapped to the valence list, we get the coordination problem that was mentioned above.

\subsection{Discontinuous Constituents and Modification of (Quasi) Lexical Elements}

In Müller, 2002, Chapter 4, I suggest an analysis that assumes that depictives attach to (quasi) lexical elements. They can either attach to lexical verbs or to verbal complexes, which are treated as lexical units. For examples like (18) on page $8 \mathrm{He}$ assumes a discontinuous constituent consisting of adjunct and verb. The analysis is shown in figure 2 on the next page. Since nackt is combined directly with hilft,

\footnotetext{
${ }^{14}$ (26b) was taken from Pollard and Sag, 1994, p. 303 and adapted to the notation used in more recent HPSG publications.

${ }^{15}$ Note that binding accounts that rely on c-command have problems with non-overt subjects in passive constructions, since even if empty elements are assumed as subjects, they do not bear a theta role. For Binding Theories like the one by Pollard and Sag (1994), which operates on argument structure, non-overt antecedents are no problem.
} 


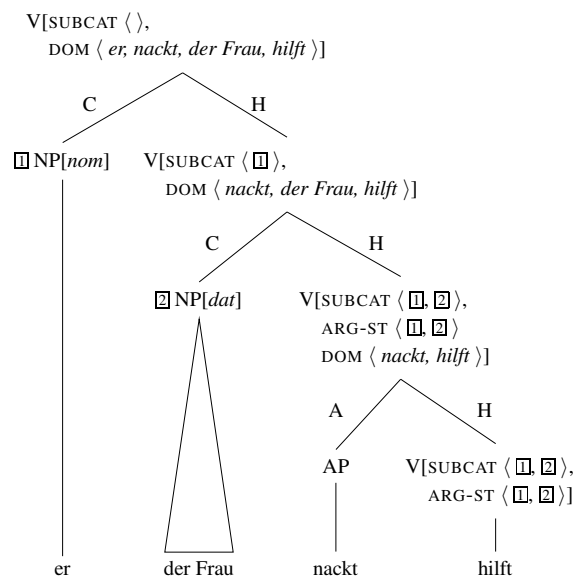

Figure 2: Binary Branching Structures and Depictive Predicates (Discontinuous)

reference to the argument structure is possible. nackt is inserted into the constituent order domain of its head hilft. See Müller, 2002, p. 28 for the constraints on domain formation that I assume. After combining these two elements the resulting projection is combined with the dative object and with the subject. The dative object der Frau is inserted into the domain between nackt and hilft.

Since it is possible to have more than one depictive predicate per clause, ARGST has to be present at the node dominating nackt and hilft. In the treatment of adjuncts suggested in Müller, 2002, adjunction did not change the lexical/phrasal status of elements. The result of adjunction to lexical elements resulted in (quasi) lexical elements.

As mentioned in the introduction, the linearization approach has problems with multiple fronting data like (19). It is possible to account for the data by using an empty verbal head, but this would be a stipulation of an entity not needed elsewhere in the grammar.

In addition my earlier approach has problems in accounting for the linearization facts, discussed in Section 2.5. The problem is discussed in more detail in the following subsection.

\subsection{Linearization Rules}

In Müller, 2002, p. 202 I suggested the following linearization rule, which was supposed to model the fact that the antecedent has to precede the depictive predicate in the local linearization domain:

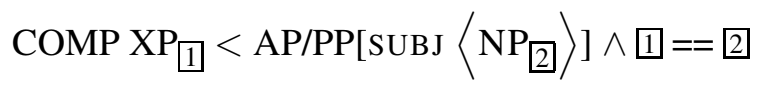

This rule accounts for the markedness/unacceptability of sentences in which an XP that is coindexed with the subject of the predicate follows the predicate.

The rule correctly excludes the coindexing of er or die Äpfel with the subject of ungewaschen in (28). 
Unfortunately it also excludes the coindexation of the subject of nackt with the reflexive in (29):

(29) weil sie $_{i}$ nackt $_{i} \operatorname{sich}_{i}$ selbst sah. because she naked her self saw

'because she saw herself naked.'

Since the linearization rule is violated, the sentence should be ungrammatical or at least marked, which it is not. The purpose of the rule is to regulate the order of sie and nackt in (29). That the sich is also coindexed with the subject of nackt is due to the fact that sie is coindexed with the subject of nackt and sich is coindexed with sie. This coindexation of personal pronoun and reflexive results in a situation in which the linearization rule in (27) makes wrong predictions.

It could be argued that depictives should not refer to reflexives in the first place, since sentences like (30) are not ambiguous.

(30) weil sie sich nackt sah.

because she herself naked saw

'because she saw herself naked.'

If reference to reflexives is admitted, we get two analyses for (30): one in which the depictive is coindexed with the reflexive and another one in which it is coindexed with the personal pronoun. However, such analyses may not be ruled out by a general ban on coindexing with reflexives, since sentences like (31) are possible:

(31) weil der König sich nackt rasieren ließ

because the king himself naked shave let

'because the king let somebody shave him naked.'

(31) has a reading in which nackt scopes over rasieren. rasieren has two arguments: the one referring to the one who does the shaving and the one who is shaved. In order to get the preferred reading, nackt has to predicate over the reflexive, which fills the argument slot of the shaved person.

After the discussion of shortcomings of earlier proposals, I now turn to the analysis. Before I come to the analysis of depictives in Section 5, I want to discuss some basic assumptions I make for the analysis of the German clause structure in the next section.

\section{Basic Assumptions about the German Clause Structure}

Following the tradition in Transformational Grammar and proposals by Bach and Fourquet (Fourquet, 1957; Bierwisch, 1963, p. 34; Bach, 1962; Reis, 1974; Thiersch, 1978, Chapter 1), I assume that German is a verb final language and that verb 
initial sentences are related to verb final ones. I assume that there is a verbal trace in the position that would be occupied by the finite verb in verb last sentences and that this trace is bound by a verb in initial position. For details of the implementation see (Kiss, 1995a; Meurers, 2000, p. 206-208). A discussion of verb movement can also be found in Frank, 1994. One reason for assuming such a verb movement analysis as opposed to flat structures or linearization approaches are cases of multiple frontings like those in (19). As is argued in Müller, To Appear 2005b, these sentences are best analyzed with an empty verbal head in front of the finite verb. The empty verbal head is the same empty element that is used in verb movement analyses and the lexical rule that licenses it is parallel to the verb movement lexical rule used by Kiss (1995a) and others modulo verbal complex formation.

As is well known, constituents can be ordered rather freely in German. For instance, both orders of arguments are possible in sentences like (32):

a. weil ein Mann dem Kind hilft.

because a man the child helps

'because a man helps the child.'

b. weil dem Kind ein Mann hilft

because the child a man helps

I assume an approach to scrambling that is similar to approaches that assumed a SUBCAT set (Gunji, 1986; Hinrichs and Nakazawa, 1989; Pollard, 1996). Instead of assuming a set, I assume a SUBCAT list and a relational constraint that deletes the argument daughter from the SUBCAT list of the head daughter when two elements are combined with the head argument schema: ${ }^{16}$

\section{Schema 1 (Head Argument Schema)}

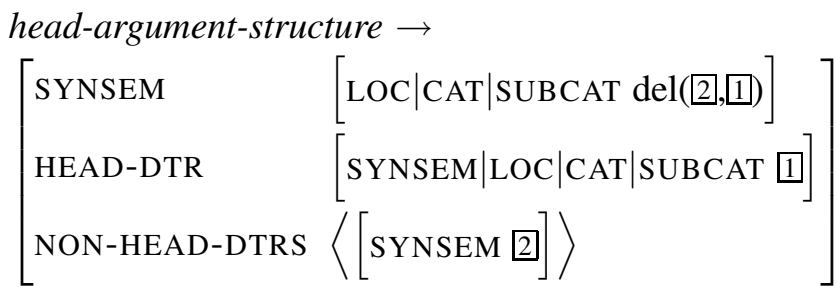

The reader who is interested in the interaction with verbal complex formation, the details of the verb movement analysis, and a discussion of alternative proposals is referred to Müller, To Appear 2005a.

\section{The Analysis of German Depictive Secondary Predicates}

As was shown in Section 2.5, the antecedent has to precede the depictive secondary predicate. This is accounted for straightforwardly in the theory outlined in the last

\footnotetext{
${ }^{16}$ See also Frank and Reyle, 1992, p. 185 and Kiss (1995b, p. 218-223) for a similar treatment of constituent order.
} 
section, if we assume that the subject of the depictive predicate is coindexed with an element in the SUBCAT list of the verbal head it combines with. For the examples in (16) we get the structures in (33):

(33) a. weil [er [die Äpfel [ungewaschen ißt]]].

because he the apples unwashed eats

'because he eats the apples unwashed.'

(He is unwashed or the apples are unwashed.)

b. weil [er [ungewaschen [die Äpfel ißt]]].

because he unwashed the apples eats

'because he eats the apples unwashed.'

(He is unwashed.)

c. * weil [ungewaschen [er/der Mann [die Äpfel ißt]]].

because unwashed he the man the apples eats

In (33a) the depictive is directly combined with the verb and the SUBCAT list of $i \beta t$ contains both the subject and the object. Therefore the account predicts that both elements are antecedent candidates for ungewaschen.

In (33b) the adjective is combined with a projection of i $\beta t$ that contains the object of $i \beta t$. Therefore the object is not an element of the SUBCAT list of this projection and only the subject is a possible antecedent of ungewaschen.

In the last case der Mann die Äpfel i $\beta t$ is fully saturated. The SUBCAT list of this projection is empty. Since there is no possible antecedent for the depictive, the sentence is rejected by the grammar.

Since I assume that verb initial sentences involve a verbal trace at the position that the finite verb would occupy in verb final sentences, verb initial sentences with depictives can be analyzed in parallel to their verb last counterparts:

(34) $\mathrm{IBt}_{i}$ [er [die Äpfel [ungewaschen_il]]?

eats he the apples unwashed

'Does he eat the apples unwashed?'

(He is unwashed or the apples are unwashed.)

Since both the subject and the object are elements of the SUBCAT list of the verbal trace, both are antecedent candidates of the depictive adjective.

Note that approaches like the ones suggested by Kiss and Wesche (1991, p. 225), Schmidt et al. (1996), and Crysmann (2003), which assume a left branching analysis for (some) verb initial sentences are incompatible with such an analysis, since they would rule out (34). (34) would have the structure in (35):

(35) [[[Ißt er] die Äpfel] ungewaschen]?

eats he the apples unwashed

Since the SUBCAT list of I $\beta$ t er die Äpfel is the empty list, there would not be any antecedent candidate for ungewaschen in the SUBCAT list of this projection.

Before I dicuss the lexical rule for depictive secondary predicates that is the core of the analysis, I want to come back to the possibility to refer to non-overt 
antecedents, which was discussed in Section 2.1. Example (3a) shows that depictive secondary predicates may predicate over subjects that are not realized at the surface. In approaches that use blocking/deblocking techniques to account for the perfect and the passive with a single lexical item for the second participle (Haider, 1986; Heinz and Matiasek, 1994), such data is unproblematic. In the lexical item for gegessen the subject is blocked. It can be deblocked by the perfect auxiliary as in (36a) or it can remain blocked as in the passive example in (36b):

a. Er hat den Apfel gegessen.

he has the appel eaten

b. Der Apfel wurde gegessen.

the appel was eaten

In HPSG grammars of German such blocked elements are usually represented as the value of a feature like DA (for designated argument) or SUBJ (for subject). Since the subject is contained in the lexical item of the participle, it is possible for the depictive to access it: Depictive secondary predicates can refer to an element of a list that is a concatenation of the SUBJ list and the SUBCAT list of the verbal element they modify. Following Pollard (1996) and Kiss (1995a), I assume that the SUBJ list of finite verbs is the empty list, since the subject of a finite verb is listed as an element of SUBCAT. So the extension that allows depictives to refer to elements of SUBJ is only relevant for non-finite verbs and for participles.

The lexical rule in (37) maps a predicative element onto an adjunct that can modify a verbal element. The SUBJ and the SUBCAT list of the modified element (3 and 4) are appended by the relational constraint append (' $\oplus$ ') and the member relation chooses nondeterministically one of the elements from the list that results from the append relation. The chosen element is coindexed with the subject of the input predicate (10).

The semantics of the input predicate (2) and the semantics of the modified head (5) are combined in the semantic representation of the output of the lexical rule.

In Müller, 2002, Chapter 4.1.1.2, I show that the obliqueness hierarchy plays a role in accounting for the different markedness of antecedent choices. So sentences with a depictive predicate that predicates over a dative argument are more marked than those where the predicate predicates over an accusative object or a subject. This can be captured in the current approach with reference to semantic obliqueness. Since the semantic contribution of the modified verbal element is accessible (5) the relative semantic obliqueness of the antecedent can be determined.

\section{Other Languages}

This analysis of German depictives works very well and it does not rely on the projection of the argument structure. However, languages with more rigid constituent order cannot be analyzed with respect to the saturatedness of projections to which 
(37) Lexical Rule that maps predicative elements onto depictive predicates:

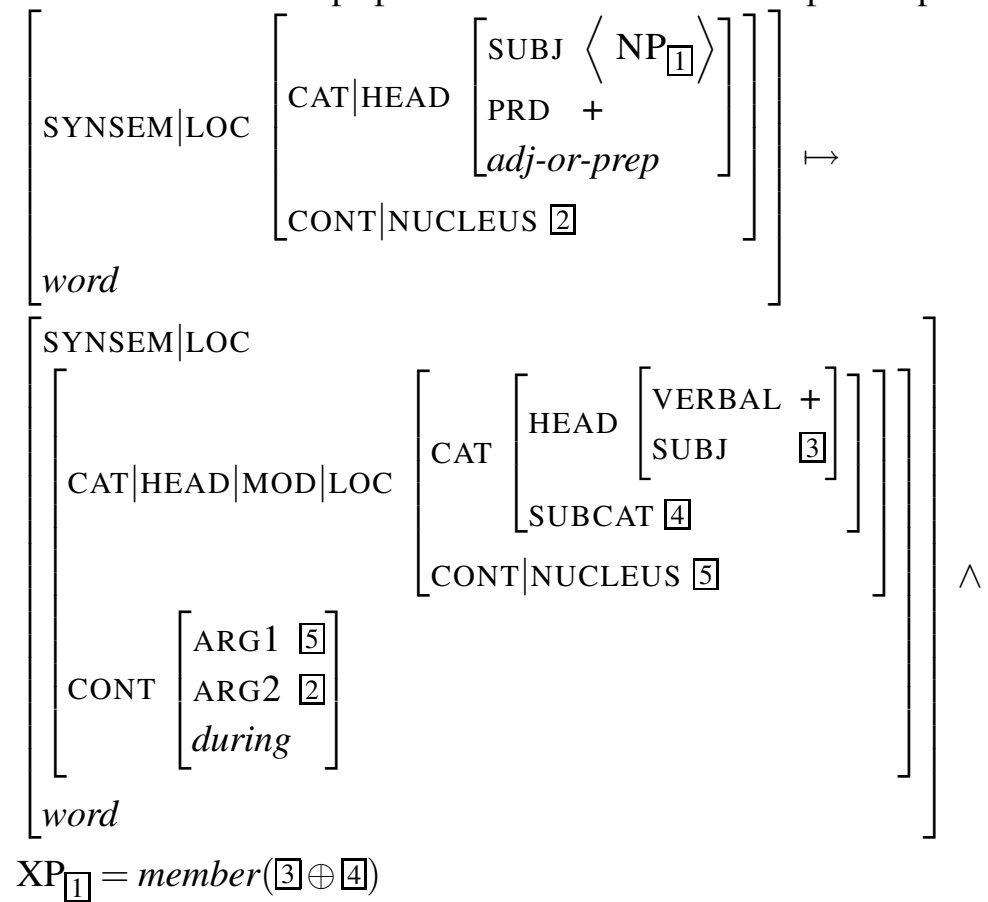

depictives attach. An example for such a language is English. Sentences like (38) are usually analyzed so that the depictive adjoins to the VP:

(38) He [[eats the fish] raw].

This means that the antecedent of raw is not contained in the valence list of eats when the depictive is combined with the verbal projection. To account for the English data only three options remain: 1) Binding Theory, 2) Adjuncts as Complements, 3) projecting the Argument Structure. Since 1) needs 2) to work properly and since 2) yields scope problems, 3) seems to be the only option left for dealing with depictives in English. There seem to be other phenomena in grammar that make the projection of argument structure necessary. For example, Kiss, 2001 suggests an analysis of quantifier scope that relies on the projection of the argument structure.

One could claim that depictives universally are analyzed with reference to the argument structure and that the linearization rules for German in addition refer to the saturatedness of verbal projections.

\section{Conclusion}

I developed an analysis of depictive secondary predicates that does not rely on discontinuous constituents. Since discontinuous constituents are a very powerful 
device, an approach that can avoid them is favorable.

The analysis does not refer to the argument structure of heads and therefore it is not necessary to assume flat structures, a lexical introduction of adjuncts, or a projection of the argument structure.

The analysis can explain why antecedents have to precede the depictive predicates without referring to linear precedence rules, which are difficult to formalize, since coindexing of arguments is involved and reflexives may interfere.

\section{References}

Bach, Emmon. 1962. The Order of Elements in a Transformational Grammar of German. Language 8(3), 263-269.

Baker, Mark C. 1988. Incorporation. A Theory of Grammatical Function Change. Chicago, London: University of Chicago Press.

Bierwisch, Manfred. 1963. Grammatik des deutschen Verbs. studia grammatica II, Berlin: Akademie Verlag.

Bouma, Gosse, Malouf, Rob and Sag, Ivan. 2001. Satisfying Constraints on Extraction and Adjunction. Natural Language and Linguistic Theory 19(1), 1-65.

Bresnan, Joan. 1982. Control and Complementation. Linguistic Inquiry 13(3), 343-434.

Chomsky, Noam. 1986. Knowledge of Language - Its Nature, Origin, and Use. Convergence, New York, Westport: Connecticut, London: Praeger.

Chomsky, Noam. 1993. Lectures on Government and Binding. Berlin, New York: Mouton de Gruyter, 7. edition.

Cipollone, Domenic. 2001. Morphologically Complex Predicates in Japanese and What They Tell us about Grammar Architecture. OSU Working Papers in Linguistics 56, Ohio State Univerity.

Crysmann, Berthold. 2003. On the Efficient Implementation of German Verb Placement in HPSG. In Proceedings of RANLP 2003, pages 112-116, Borovets, Bulgaria.

Eisenberg, Peter. 1994. Grundriß der deutschen Grammatik. Stuttgart, Weimar: Verlag J. B. Metzler, third edition.

Fourquet, Jean. 1957. Review of: Heinz Anstock: Deutsche Syntax - Lehr und Übungsbuch. Wirkendes Wort 8, 120-122.

Frank, Anette. 1994. Verb Second by Lexical Rule or by Underspecification. Arbeitspapiere des SFB 340 No. 43, IBM Deutschland GmbH, Heidelberg.

Frank, Annette and Reyle, Uwe. 1992. How to Cope With Scrambling and Scope. In Günther Görz (ed.), Konvens 92. 1. Konferenz ,, Verarbeitung natürlicher Sprache“. Nürnberg 7.-9. Oktober 1992, Informatik aktuell, pages 178-187, Berlin, Heidelberg, New York: Springer-Verlag.

Grewendorf, Günther. 1989. Ergativity in German. Studies in Generative Grammar, No. 35, Dordrecht: Holland, Providence: U.S.A.: Foris Publications.

Grewendorf, Günther. 1993. German. A Grammatical Sketch. In Joachim Jacobs, Arnim von Stechow, Wolfgang Sterenfeld and Theo Vennemann (eds.), Syntax - Ein internationales Handbuch zeitgenössischer Forschung, volume 9.2 of Handbücher zur Sprachund Kommunikationswissenschaft, pages 1288-1319, Berlin: Walter de Gruyter Verlag.

Gunji, Takao. 1986. Subcategorization and Word Order. In William J. Poser (ed.), Papers from the Second International Workshop on Japanese Syntax, pages 1-21, Stanford: CSLI Publications.

Haider, Hubert. 1985. The Case of German. In Jindřich Toman (ed.), Studies in German 
Grammar, Studies in Generative Grammar, No. 21, pages 23-64, Dordrecht: Holland, Cinnaminson: U.S.A.: Foris Publications.

Haider, Hubert. 1986. Fehlende Argumente: vom Passiv zu kohärenten Infinitiven. Linguistische Berichte 101, 3-33.

Haider, Hubert. 1993. Deutsche Syntax - generativ. Vorstudien zur Theorie einer projektiven Grammatik. Tübingen: Gunter Narr Verlag.

Haider, Hubert. 1997. Precedence among Predicates. The Journal of Comparative Germanic Linguistics 1, 2-41.

Heinz, Wolfgang and Matiasek, Johannes. 1994. Argument Structure and Case Assignment in German. In John Nerbonne, Klaus Netter and Carl J. Pollard (eds.), German in HeadDriven Phrase Structure Grammar, pages 199-236, Stanford: CSLI Publications.

Helbig, Gerhard and Buscha, Joachim. 1972. Deutsche Grammatik. Ein Handbuch für den Ausländerunterricht. Leipzig: VEB Verlag Enzyklopädie.

Hinrichs, Erhard W. and Nakazawa, Tsuneko. 1989. Subcategorization and VP Structure in German. In Aspects of German VP Structure, SfS-Report-01-93, Eberhard-Karls-Universität Tübingen.

Jacobs, Joachim. 1994. Das lexikalische Fundament der Unterscheidung von obligatorischen und fakultativen Ergänzungen. Zeitschrift für Germanistische Linguistik 22, 284 319.

Jacobs, Joachim. 1997. I-Topikalisierung. Linguistische Berichte 168, 91-134.

Jaeggli, Osvaldo A. 1986. Passive. Linguistic Inquiry 17(4), 587-622.

Kasper, Robert T. 1994. Adjuncts in the Mittelfeld. In John Nerbonne, Klaus Netter and Carl J. Pollard (eds.), German in Head-Driven Phrase Structure Grammar, pages 3970, Stanford: CSLI Publications.

Kaufmann, Ingrid. 1995. Konzeptuelle Grundlagen semantischer Dekompositionsstrukturen. Die Kombinatorik lokaler Verben und prädikativer Elemente. Linguistische Arbeiten, No. 335, Tübingen: Max Niemeyer Verlag.

Kaufmann, Ingrid and Wunderlich, Dieter. 1998. Cross-linguistic Patterns of Resultatives. SFB 282: Theorie des Lexikons 109, Heinrich Heine Uni/BUGH, Düsseldorf.

Kiss, Tibor. 1995a. Infinite Komplementation. Neue Studien zum deutschen Verbum infinitum. Linguistische Arbeiten, No. 333, Tübingen: Max Niemeyer Verlag.

Kiss, Tibor. 1995b. Merkmale und Repräsentationen. Opladen/Wiesbaden: Westdeutscher Verlag.

Kiss, Tibor. 2001. Configurational and Relational Scope Determination in German. In Walt Detmar Meurers and Tibor Kiss (eds.), Constraint-Based Approaches to Germanic Syntax, pages 141-175, Stanford: CSLI.

Kiss, Tibor and Wesche, Birgit. 1991. Verb Order and Head Movement. In O. Herzog and C.-R. Rollinger (eds.), Text Understanding in LILOG, pages 216-242, Springer-Verlag.

Koch, Wolfgang and Rosengren, Inger. 1995. Secondary Predications: Their Grammatical and Conceptual Structure. Forschungsprogramm Sprache und Pragmatik 35, Germanistisches Institut der Universität Lund, Lund.

Koizumi, Masatoshi. 1994. Secondary Predicates. Journal of East Asian Linguistics 3, 2529.

Levine, Robert D. 2003. Adjunct Valents, Cumulative Scopings and Impossible Descriptions. In Jongbok Kim and Stephen Wechsler (eds.), The Proceedings of the 9th International Conference on Head-Driven Phrase Structure Grammar, pages 209-232, Stanford, CA: CSLI Publications, http://cslipublications.stanford.edu/HPSG/3/.

Lötscher, Andreas. 1985. Syntaktische Bedingungen der Topikalisierung. Deutsche Sprache 13, 207-229. 
Meurers, Detmar. 2000. Lexical Generalizations in the Syntax of German Non-Finite Constructions. Arbeitspapiere des SFB 340 No. 145, Eberhard-Karls-Universität, Tübingen.

Müller, Stefan. 1999. Deutsche Syntax deklarativ. Head-Driven Phrase Structure Grammar für das Deutsche. Linguistische Arbeiten, No. 394, Tübingen: Max Niemeyer Verlag.

Müller, Stefan. 2002. Complex Predicates: Verbal Complexes, Resultative Constructions, and Particle Verbs in German. Stanford: CSLI.

Müller, Stefan. 2003. Mehrfache Vorfeldbesetzung. Deutsche Sprache 31(1), 29-62.

Müller, Stefan. 2004. Continuous or Discontinuous Constituents? A Comparison between Syntactic Analyses for Constituent Order and Their Processing Systems. Research on Language and Computation 2(2), 209-257.

Müller, Stefan. To Appear 2005a. Zur Analyse der deutschen Satzstruktur. Linguistische Berichte http://www.cl.uni-bremen.de/ stefan/Pub/satz-lb.html. 03.10.2004.

Müller, Stefan. To Appear 2005b. Zur Analyse der scheinbar mehrfachen Vorfeldbesetzung. Linguistische Berichte .

Neeleman, Ad. 1994. Complex Predicates. Ph. D.thesis, Onderzoeksinstituut voor Taal en Spraak (OTS), Utrecht.

Paul, Hermann. 1919. Deutsche Grammatik. Teil IV: Syntax, volume 3. Halle an der Saale: Max Niemeyer Verlag, 2nd unchanged edition 1968, Tübingen: Max Niemeyer Verlag.

Plank, Frans. 1985. Prädikativ und Koprädikativ. Zeitschrift für Germanistische Linguistik 13, 154-185.

Pollard, Carl J. 1996. On Head Non-Movement. In Harry Bunt and Arthur van Horck (eds.), Discontinuous Constituency, pages 279-305, Berlin, New York: Mouton de Gruyter, published version of a Ms. dated January 1990.

Pollard, Carl J. and Sag, Ivan A. 1994. Head-Driven Phrase Structure Grammar. University of Chicago Press.

Reis, Marga. 1974. Syntaktische Haupsatzprivilegien und das Problem der deutschen Wortstellung. Zeitschrift für Germanistische Linguistik 2(3), 299-327.

Rothstein, Susan D. 1985. The Syntactic Forms of Predication. Ph. D.thesis, Bar-Ilan University, reproduced by the Indiana University Linguistics Club.

Schmidt, Paul, Rieder, Sibylle and Theofilidis, Axel. 1996. Final Documentation of the German LS-GRAM Lingware. Deliverable DC-WP6e (German), IAI, Saarbrücken.

Simpson, Jane. In Preparation. Depictives in English and Warlpiri. In Nikolaus P. Himmelmann and Eva Schultze-Berndt (eds.), Secondary Predication and Adverbial Modification. Crosslinguistic Explorations in the Syntax and Semantics of Depictives, Oxford: Oxford University Press.

Thiersch, Craig L. 1978. Topics in German Syntax. Dissertation, M.I.T.

Uszkoreit, Hans. 1987. Word Order and Constituent Structure in German. CSLI Lecture Notes, No. 8, Stanford: CSLI Publications.

van Noord, Gertjan and Bouma, Gosse. 1994. The Scope of Adjuncts and the Processing of Lexical Rules. In Proceedings of COLING 94, pages 250-256, Kyoto Japan.

von Stechow, Arnim and Sternefeld, Wolfgang. 1988. Bausteine syntaktischen Wissens. Ein Lehrbuch der Generativen Grammatik. Opladen/Wiesbaden: Westdeutscher Verlag.

Winkler, Susanne. 1997. Focus and Secondary Predication. Studies in Generative Grammar, No. 43, Berlin, New York: Mouton de Gruyter.

Wunderlich, Dieter. 1997. Argument Extension by Lexical Adjunction. Journal of Semantics 14(2), 95-142.

Zifonun, Gisela. 1997. Das Passiv. In Hans-Werner Eroms, Gerhard Stickel and Gisela Zifonun (eds.), Grammatik der deutschen Sprache, pages 1788-1858, Berlin, New York: Walter de Gruyter. 